\begin{tabular}{|c|l|}
\hline Title & Efficient Synthesis of Photoreactive 2-Propoxy aniline Derivatives as Artificial Sweeteners \\
\hline Author(s) & $\begin{array}{l}\text { Hashimoto, Makoto; Murai, Y uta; Y oshida, Takuma; W ang, Lei; Masuda, Katsuy oshi; Hashidoko, Y asuyuki; Monde, } \\
\text { Kenji; Hatanaka, Y asumaru }\end{array}$ \\
\hline Citation & $\begin{array}{l}\text { Synlett, 27(06), 946-950 } \\
\text { https://doi.org/10.1055/s0035-1561275 }\end{array}$ \\
\hline Issue Date & 2016-04 \\
\hline Doc URL & http://hdl.handle.net/2115/64990 \\
\hline Rights & これは出版社に投稿した著者最終原稿です。This is the accepted manuscript. \\
\hline Type & article (author version) \\
\hline File Information & 6 Synlett 27 946-950 word.pdf \\
\hline
\end{tabular}

Instructions for use 


\section{Efficient Synthesis of Photoreactive 2-Propoxyaniline Derivatives as Artificial Sweeteners}

Yuta Murai*a,b
Takuma Yoshida $^{\mathrm{b}}$
Lei Wang $^{\mathrm{b}}$
Katsuyoshi Masuda $^{\mathrm{c}}$
Yasuyuki Hashidoko $^{\mathrm{b}}$
Kenji Monde $^{\mathrm{a}}$
Yasumaru Hatanaka $^{\mathrm{d}}$
Makoto Hashimoto*b $^{\text {b }}$

${ }^{\mathrm{a} F a c u l t y}$ of Advanced Life Science, Frontier Research Center for Post-Genome Science and Technology, Hokkaido University, Kita 21, Nishi 11, Kita-ku, Sapporo 001-0021.

${ }^{b}$ Division of Applied Science, Graduate School of Agriculture, Hokkaido University; Kita 9, Nishi 9, Kita-ku, Sapporo 0608589 .

'Suntory Institute for Bioorganic Research, 1-1-1 Wakayamadai, Shimamoto-cho, Mishima-gun, Osaka 6188503.

${ }^{\mathrm{d}}$ Graduate School of Medicine and Pharmaceutical Sciences, University of Toyama, 2630 Sugitani, Toyama 930-0194.

E-mail:ymurai@mail.sci.hokudai.ac.jp

E-mail: hasimoto@abs.agr.hokudai.ac.jp

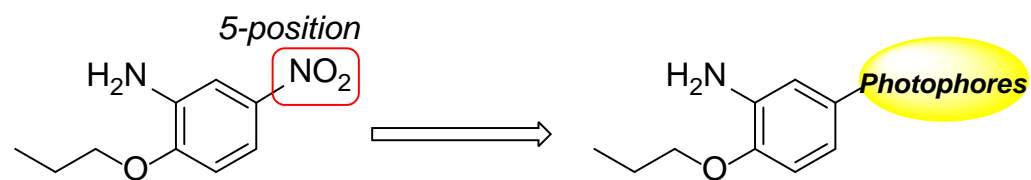

5-nitro-2-propoxyaniline

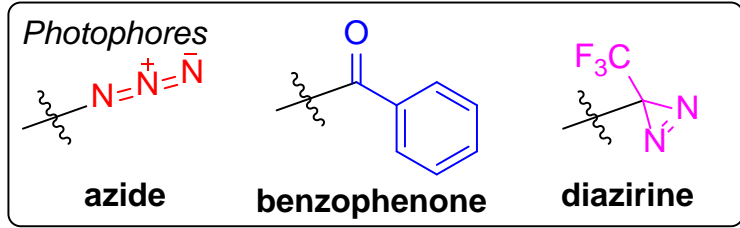

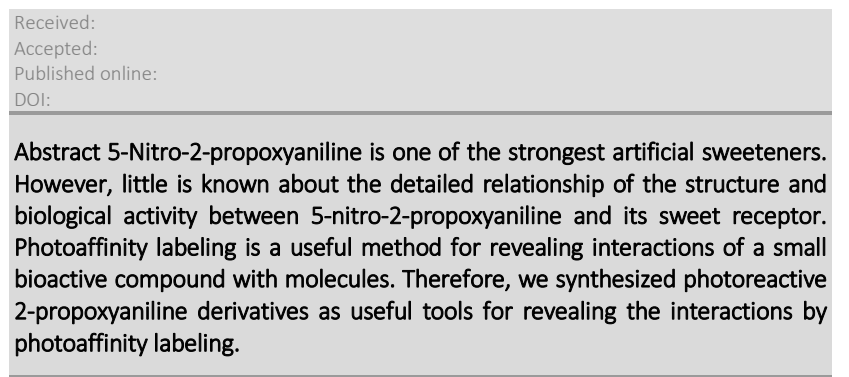

Key words photoaffinity labeling, chemical biology, photophore, artificial sweetener, sweet receptor

\section{Introduction:}

5-Nitro-2-propoxyaniline (1, Figure 1), named P-4000, has a sweetness intensity that is approximately 4000-times greater than that of sucrose and is well known as one of the strongest artificial sweeteners. ${ }^{1}$ On the other hand, it was once used as an artificial sweetener, but its use has been banned because of its possible toxicity. ${ }^{2}$ It is known that sweet taste is recognized by a sweetener binding with the sweet receptor, which is a heterodimeric receptor consisting of T1R2 and T1R3 subunits. ${ }^{3}$ However, the mechanism of sweetness and toxicity of 5-nitro-2-propoxyaniline has still not been elucidated. Elucidation of the interactions between artificial sweeteners and their sweet receptor has attracted much interest and many researchers have studied the interactions by using NMR spectroscopy ${ }^{4}$ and $\mathrm{X}$-ray crystallography. ${ }^{5}$ There have been only a few studies using homology modeling to determine the mechanism of action of 5-nitro-2-propoxyaniline for the gustatory receptor. ${ }^{6}$ However, satisfactory results have not been obtained, the detailed mechanism of action of 5-nitro-2-propoxyaniline for the receptor has not been elucidated. Identification of the biological mechanism as well as that of the target protein is a crucial point in the field of chemical biology. Photoaffinity labeling is one of the most powerful chemical tools to reveal interactions of bioactive compounds with biomolecules instead of X-ray crystallography and the solution-state NMR method, which are difficult to apply to a membrane protein such as the gustatory receptor. It is suitable for the analysis of biological interactions based on the affinity of biological active compounds for biomolecules. Therefore we have reported that synthesis of several photoaffinity labeling reagent for gustatory receptor. $^{7}$

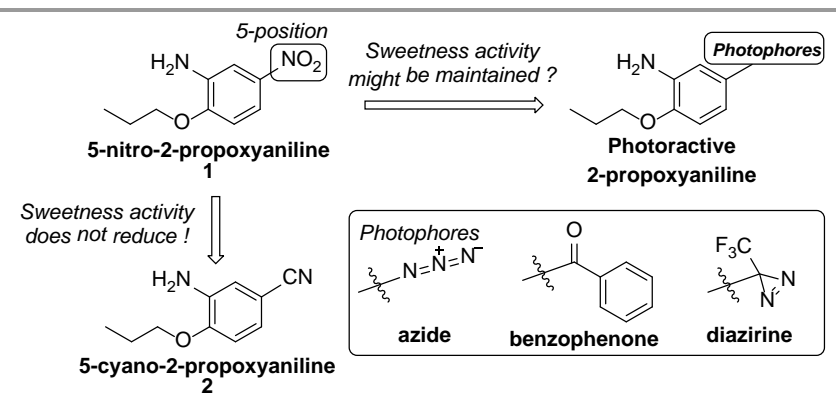

Figure 1 Structure of 5-nitro-2-propoxyaniline (1) and 5-cyano-2 propoxyaniline (2). The nitro group of 5-nitro-2-propoxyaniline was converted to photoreactive groups in this study

To the best of our knowledge, synthesis of photoreactive-2propoxyaniline derivatives for photoaffinity labeling has not been reported yet. According to a previous report ${ }^{8}$, even though the nitro group of 5-nitro-2-propoxyaniline was converted to a cyano group, there was almost no decrease in sweetness activity (2, Figure 1). Modification at the 5-position of 2-propoxyaniline might be useful for the introduction of photophores into the ligand skeleton. Therefore, we decided to synthesize 2-propoxyaniline-substituted photophores at the 5-position. Photophores, typically three types, arylazide, benzophenone and aryldiazirine, are used in photoaffinity labeling. To obtain good results using photoaffinity labeling, 
selection of an appropriate photophore is important. ${ }^{9}$ In this paper, the synthesis of each photoreactive 2-propoxyaniline derivative with aryl azide, benzophenone and aryl diazirine and also the results of sweet-tasting effect assay for determining biological activities of photoreactive compounds are reported.

\section{Results and Discussion:}

The synthesis of 5-azide-2-propoxyaniline (6) started with commercially available 4-propoxy bromobenzene (3) to synthesize (6) efficiently with a few steps. Because an azide group often cannot tolerate strong acidic condition or reductive condition, we decided to install an azide group in the final step. First, compound (3) was subjected to electrophilic nitration with nitric acid (fuming) in acetic anhydride ${ }^{10}$ to obtain compound (4) without ipso nitration. Subsequently, since $\mathrm{H}_{2}-\mathrm{Pd} / \mathrm{C}$ reductive condition of the nitro group was simultaneously liable to reduce the bromo group, we chose sodium dithionite to selectively reduce the nitro group and afforded 5 -bromo-2-propoxyaniline (5) in 78\% yield. Finally, the bromo group in compound (5) was substituted with an azide group by sodium azide through $\mathrm{Cu}^{\prime}$-catalyzed reaction ${ }^{11}$ to obtain compound (6). ${ }^{12}$ (Scheme 1)

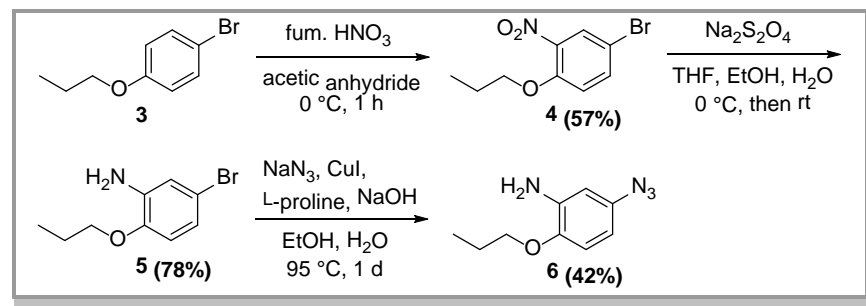

Scheme 1 Synthesis of 5-azide-2-propoxyaniline

We next tried to synthesize benzophenone derivative (10) from compound (4) as the common intermediate. Although the bromide of (4) was subjected to lithiation with $n$-BuLi followed by treatment with benzoylated reagents to produce a benzophenone moiety, the products were complicated. Consequently, we considered an alternative synthesis strategy for constructing compound (10), and it was prepared from commercially available $\mathrm{N}-(2-$ hydroxyphenyl)acetamide (7) according to similarly previous methods. Compound (7) was subjected to Williamson ether synthesis with 1-bromopropane ${ }^{13}$ to produce (8) in high yield. Subsequently, Friedel-Crafts benzoylation between compound (8) and benzoyl chloride with $\mathrm{AlCl}_{3}$ at room temperature ${ }^{14}$ for $3 \mathrm{~h}$ gave compound (9), and this was followed by deprotection of the acetyl group under an acidic condition to afford the benzophenone derivative $(10)^{15}$ in $84 \%$ overall yield without cleaving the ether group by a three-step sequence. (Scheme 2)

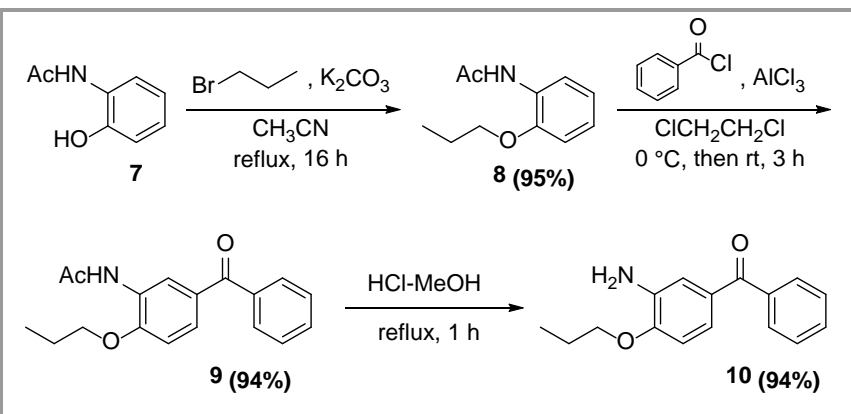

Scheme 2 Synthesis of 5-benzoyl-2-propoxyaniline

For the (trifluoromethyl)phenyldiazirine moiety, compound (4) was not available for the starting material to install a trifluoroacetyl group for the same reason in installing a benzophenone group. In addition, it was not possible to obtain a trifluoroacetyl derivative from compound (7) or (8) by Friedel-Crafts acylation. Therefore, we selected alternative starting material (11), and it was subjected to demethylation by lithium chloride under a reflux condition ${ }^{16}$ to give (12), and this was followed by Williamson ether synthesis ${ }^{17}$ to produce (15). Compound (15) was able to be prepared in another way; commercially available 4-propoxybenzaldehyde (13) was treated with $\mathrm{CF}_{3}-\mathrm{TMS}^{18}$ and worked up with $1 \mathrm{M} \mathrm{HCl}$ to obtain (14) in good yield. Compound (14) was oxidized with Dess-Martin periodinane under an acidic condition ${ }^{19}$ in excellent yield. (Scheme 3)

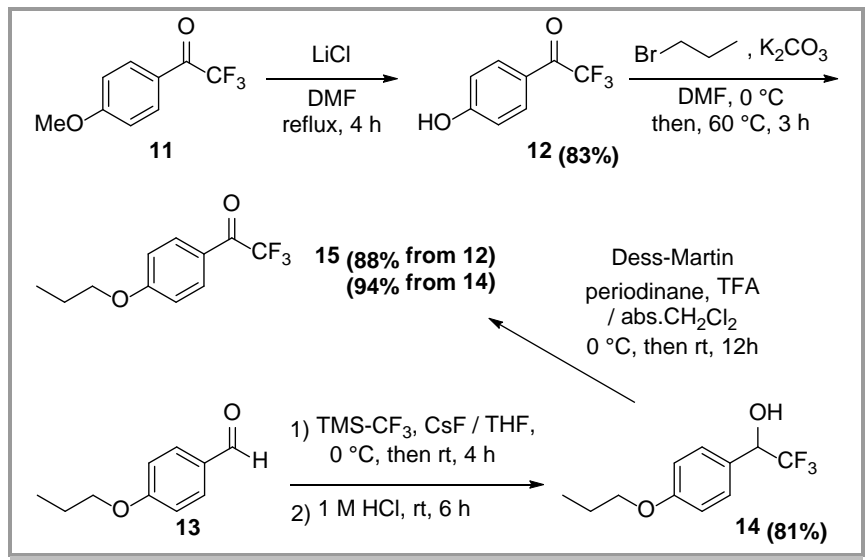

Scheme 3 Synthesis of 2,2,2-trifluoro-1-(4-propoxyphenyl)ethan-1-one

Nitration of compound (15) with fuming $\mathrm{HNO}_{3}$ in acetic anhydride at $0{ }^{\circ} \mathrm{C}$ proceeded selectively (16). The trifluoroacetyl moiety was converted to the (trifluoromethyl)diazirinyl moiety (20) using a general method. ${ }^{20}$ However, the diazirinyl moiety could not tolerate the condition in which the nitro group was reduced by $\mathrm{Na}_{2} \mathrm{~S}_{2} \mathrm{O}_{4}{ }^{21}$, and we therefore previously had the compound (19) reduced without breaking the diaziridinyl moiety and obtained (21) in moderate yield. Subsequently, the diaziridinyl moiety was converted to diazirinyl moiety $(22)^{22}$ with activated $\mathrm{MnO}_{2}$ under a mild condition. (Scheme 4)

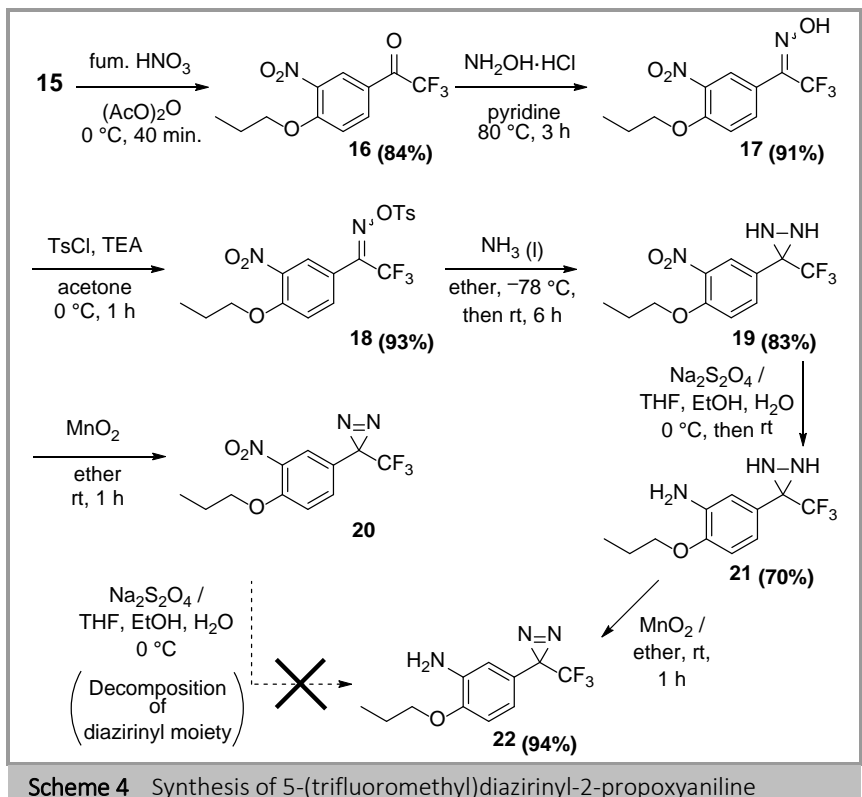

The activities of compound (6) and (22) were measured by a cellbased assay ${ }^{23}$, which determines the changes of intracellular calcium ion levels in the human sweet taste receptor hT1R2-hT1R3expressing HEK293T cells by the fluorescent calcium indicator [fura- 
2 acetoxymethyl ester] as described by Imada et al. ${ }^{24}$ Both the photoreactive 2-propoxyaniline, (6) and (22), exhibited almost the same sweetness activity as sucrose. On the other hand, compound (10) did not appreciably show the activity due to a bulky benzoyl group presumably. These results indicated that photoreactive 2propoxyaniline (6) and (22) have enough affinity with the sweet taste receptor to elucidate the binding site for the ligands in the sweet taste receptor.

\section{Conclusion:}

In summary, we have achieved for the first time a comprehensive synthesis of photoreactive (an arylazide, a benzophenone, and an aryldiazirine) 2-propoxyanilines for investigation of the sweet receptor by photoaffinity labeling. These derivatives are expected to be able to elucidate the detailed bioactive mechanism of 5-nitro-2propoxyaniline for gustatory and toxic responses.

\section{Acknowledgment}

MH thanks the Suhara Memorial and Mishima Kaiun Foundation for financial support. Part of this work was performed under the Cooperative Research Program of "Network Joint Research Center for Materials and Devices". This research was partially supported by Grantsin-Aid for Young Scientist B from the Japan Society for Promotion of Science (JSPS) (KAKENHI Grant No. 15K16552).

\section{Supporting Information}

YES (this text will be updated with links prior to publication)

\section{Primary Data}

NO (this text will be deleted prior to publication)

\section{References and Notes}

(1) Cox, W.S. J. Assoc. Off. Anal. Chem. 1953, 36, 749.

(2) G. Fitzhugh, G.; Nelson, A. A.; Frawley, J. P. J. Am. Pharm. Assoc. 1951, 40, 583.

(3) (a) Montmayeur, J-P.; Liberles, S. D.; Matsunami, H.; Buck, L. B. Nat. Neurosci. 2001, 4, 492. (b) Li, X.; Staszewski, L.; Xu, H.; Durick, K.; Zoller, M.; Adler, E. Proc Natl. Acad. Sci. USA. 2002, 99, 4692.

(4) (a) Caldwell, J. E.; Abildgaard, F.; Dzakula, Z.;Ming, D.; Hellekant G.; Markley, J. L. Nat. Struct. Mol. Biol. 1998, 5, 427. (b) Zell, M. T.; Padden, B. E.; Grant, D. J. W.; Schroeder, S. A.; Wachholder, K. L.; Prakash, I.; Munson, E. J. Tetrahedron 2000, 56, 6603. (c) Niccolai, N.; Spadaccini, R.; Scarselli, M.; Bernini, A.; Crescenzi, O.; Spiga, O.; Ciutti, A.; Maro, D. D.; Bracci, L.; Dalvit, C.; Temussi, P. A. Protein Science 2001, 10, 1498. (d) Offerdahl, T. J.; Salsbury, J. S.; Dong, Z.; Grant, D. J.; Schroeder, S. A.; Prakash, I.; Gorman, E. M.; Barich, D. H.; Munson, E. J. J. Pharm. Sci. 2005, 94, 2591. (e) Assadi-Porter, M.; Tonelli, M.; Maillet, E.; Hallenga, K.; Benard, O.; Max, M.; Markley, J. L. J. Am. Chem. Soc. 2008, 130, 7212.

(5) (a) Hatada, M. Jancarik, J. Graves, B.; Kim, S. H. J. Am. Chem. Soc. 1985, 107, 4279. (b) Feinstein, R. D.; Polinsky, A.; Douglas, A. J.; Beijer, C. M. G. F.; Chadha, R. K.; Benedetti, E.; Goodman, M. J. Am. Chem. Soc. 1991, 113, 3467.

(6) (a) Bassoli, A.; Drew, M. G. B.; Merlini, L.; Morini, G. J. Med. Chem. 2002, 45, 4402. (b) Morini, G.; Bassoli, A.; Temussi, P. A. J. Med. Chem. 2005, 48, 5520.

(7) (a) Masuda, K.; Koizumi, A.; Misaka, T.; Hatanaka, Y.; Abe, K.; Tanaka, T.; Ishiguro, M.; Hashimoto, M. Bioorg. \& Med. Chem. Lett. 2010, 20, 1081. (b) Tsunekawa, Y.; Masuda, K.; Muto, M.; Muto, Y.; Murai, Y.; Hashidoko, Y.; Orikasa, Y.; Oda, Y.; Hatanaka, Y.; Hashimoto, M. Heterocycles 2012, 84, 283. (c) Sakurai, M.; Masuda, K.; Wang, L.; Murai, Y.; Sakihama, Y.; Hashidoko, Hatanaka, Y.; Hashimoto, M. Heterocycles 2014, 88, 629. (d) Sakurai, M.; Yoshida, T.; Wang, L.; Murai, Y.; Masuda, K.; Sakihama,
Y.; Hashidoko, Y.; Hatanaka, Y.; Hashimoto, M. Heterocycles, 2015 90, 698. (e) Wang, L.; Yoshida, T.; Muto, Y.; Murai, Y.; Tachrim, Z. P.; Ishida, A.; Nakagawa, S.; Sakihama, Y.; Hashidoko, Y.; Masuda, K.; Hatanaka, Y.; Hashimoto, M. Eur. J. Org. Chem. 2015, 3129.

(8) Iwamura, H. J. Med. Chem. 1980, 23, 308.

(9) Hashimoto, M.; Hatanaka, Y. Eur. J. Org. Chem. 2008, 2513.

(10) Clewley, R. G.; Fischer, A.; Henderson, G. N. Can. J. Chem. 1989, 67, 1472.

(11) Andersen, J.; Madsen, Ulf.; Bjorkling, F.; Liang, X.; Synlett 2005, 14, 2209.

(12) 5-Azido-2-propoxyaniline (6)

Compound 5 ( $57.3 \mathrm{mg}, 0.25 \mathrm{mmol}$ ), $\mathrm{NaN}_{3}(32.3 \mathrm{mg}, 0.5 \mathrm{mmol}$ ), CuI (4.74 mg, $24.9 \mu \mathrm{mol}$ ), L-proline ( $8.6 \mathrm{mg}, 75 \mu \mathrm{mol})$ and $\mathrm{NaOH}$ (3 mg, $75 \mu \mathrm{mol}$ ) were dissolved in $70 \%$ ethanol $(500 \mu \mathrm{L}$ ). The reaction mixture was stirred for $1 \mathrm{~d}$ at $95{ }^{\circ} \mathrm{C}$ and the solution was removed. The residue was purified by silica column chromatography $\left(\mathrm{CHCl}_{3} / n\right.$-hexane $1: 1$, then AcOEt $/ n$-hexane 1:3) to yield $6(20.2 \mathrm{mg}, 42 \%)$ as brown oil.

${ }^{1} \mathrm{H}$ NMR $\left(500 \mathrm{MHz}, \mathrm{CDCl}_{3}\right): \delta=6.72(\mathrm{~d}, \mathrm{~J}=8.1 \mathrm{~Hz}, 1 \mathrm{H}), 6.39-6.34$ $(\mathrm{m}, 2 \mathrm{H}), 3.93(\mathrm{t}, \mathrm{J}=6.6 \mathrm{~Hz}, 2 \mathrm{H}), 3.90(\mathrm{brs}, 2 \mathrm{H}), 1.87-1.77(\mathrm{~m}, \mathrm{~J}=$ $7.1 \mathrm{~Hz}, 2 \mathrm{H}), 1.04(\mathrm{t}, \mathrm{J}=7.4 \mathrm{~Hz}, 3 \mathrm{H}) .{ }^{13} \mathrm{C}$ NMR $\left(126 \mathrm{MHz}, \mathrm{CDCl}_{3}\right): \delta=$ $144.1,137.7,132.6,112.3,108.2,105.4,70.2,22.6,10.6$. HRMS (ESI) $\mathrm{m} / \mathrm{z}[\mathrm{M}+\mathrm{H}]+$ calcd for $\mathrm{C}_{9} \mathrm{H}_{13} \mathrm{BrN}_{4} \mathrm{O}$ 193.1089, found 193.1090.

(13) Cao, X.; Deng, X-Q.; Shu, B.; Wang, S-B.; Quan, Z-S. Drug Res. 2013 $63,319$.

(14) Brain, C-T.; Culshaw, A-J.; Dziadulewicz, E-K.; Schopfer, U. WO 2002042248.

(15) (3-Amino-4-propoxyphenyl)(phenyl)methanone (10) $\mathrm{N}$-(5-Benzoyl-2-propoxyphenyl)acetamide 9 (100 mg, $0.34 \mathrm{mmol}$ ) was dissolved in methanol $(2 \mathrm{~mL})$ and conc. $\mathrm{HCl}(2 \mathrm{~mL})$. The mixture reacted for $1 \mathrm{~h}$ under reflux. The solution was concentrated, saturated $\mathrm{NaHCO}_{3}$ was added to the residue. The desired product was extracted with AcOEt $(2 \times 50 \mathrm{~mL})$, and dried over $\mathrm{MgSO}$, and then evaporated. The residue was purified by silica column chromatography (AcOEt/n-hexane 1:4) to yield 10 (81.0 mg, 94\%) as yellow oil.

${ }^{1} \mathrm{H}$ NMR $\left(270 \mathrm{MHz}, \mathrm{CDCl}_{3}\right): \delta=7.81-7.68(\mathrm{~m}, 2 \mathrm{H}), 7.62-7.38(\mathrm{~m}$, $3 \mathrm{H}), 7.27(\mathrm{~s}, 1 \mathrm{H}), 7.19(\mathrm{~d}, \mathrm{~J}=8.4 \mathrm{~Hz}, 1 \mathrm{H}), 6.79(\mathrm{~d}, \mathrm{~J}=8.2 \mathrm{~Hz}, 1 \mathrm{H})$, $4.04(\mathrm{t}, \mathrm{J}=6.4 \mathrm{~Hz}, 2 \mathrm{H}), 3.93$ (brs, $2 \mathrm{H}), 1.87$ (sxt, J = $7.1 \mathrm{~Hz}, 2 \mathrm{H}$ ), $1.07(\mathrm{t}, \mathrm{J}=7.4 \mathrm{~Hz}, 3 \mathrm{H}) .{ }^{13} \mathrm{C} \mathrm{NMR}\left(68 \mathrm{MHz}, \mathrm{CDCl}_{3}\right): \delta=196.2,150.6$, 138.7, 136.3, 131.7, 130.3, 129.8, 128.1, 122.7, 116.0, 109.9, 69.9, 22.4, 10.4. HRMS (ESI) $\mathrm{m} / \mathrm{z}[\mathrm{M}+\mathrm{H}]+$ calcd for $\mathrm{C}_{16} \mathrm{H}_{18} \mathrm{NO}_{2}$ 256.1338, found 256.1341.

(16) Lu, X.; Cseh, S.; Byun, H-S.; Tigyi, G.; Bittman, R. J. Org. Chem. 2003, 68,7046 .

(17) Kitamura, C.; Naito, T.; Yoneda, A.; Kobayashi, T.; Naito, H.; Komatsu, T. Chem. Lett. 2009, 38, 600.

(18) Chatterjee, A.; Oh, D. J.; Kim, K. M.; Youk, K-S.; Ahn, K. H. Chem. Asian. J. 2008, 3, 1962.

(19) Linderman, R. J.; Graves, D. M. J. Org. Chem. 1989, 54, 661.

(20) Murai, Y.; Masuda, K.; Sakihama, Y.; Hashidoko, Y.; Hatanaka, Y.; Hashimoto, M. J. Org. Chem. 2012, 77, 1092.

(21) Kosemura, S.; Emori, H.; Yamamura, S.; Anai, T.; Tomita, K.; Hasegawa, K. Tetrahedron Lett. 1997, 38, 2125.

(22) 2-Propoxy-5-(3-(trifluoromethyl)-3H-diazirin-3-yl)aniline (22)

Diaziridine 21 (38.1 mg, $0.15 \mathrm{mmol}$ ) and activated $\mathrm{MnO}_{2}$ (excess) were suspended in ether $(6 \mathrm{~mL})$. The reaction mixture was stirred at room temperature for $1 \mathrm{~h}$, then filtrated insoluble material. The filtrate was concentrated and the residue was purified by silica column chromatography $\left(\mathrm{CH}_{2} \mathrm{Cl}_{2} / n\right.$-hexane $\left.1: 3\right)$ to yield 22 (35.5 $\mathrm{mg}, 94 \%$ ) as yellow oil.

${ }^{1} \mathrm{H} \mathrm{NMR}\left(500 \mathrm{MHz}, \mathrm{CDCl}_{3}\right): \delta=6.72(\mathrm{~d}, \mathrm{~J}=8.6 \mathrm{~Hz}, 1 \mathrm{H}), 6.55(\mathrm{~s}, 1 \mathrm{H})$ $6.46(\mathrm{~d}, \mathrm{~J}=8.6 \mathrm{~Hz}, 1 \mathrm{H}), 3.94(\mathrm{t}, \mathrm{J}=6.6 \mathrm{~Hz}, 2 \mathrm{H}), 3.90(\mathrm{brs}, 2 \mathrm{H}), 1.86$ - $1.78(\mathrm{~m}, 2 \mathrm{H}), 1.03(\mathrm{t}, \mathrm{J}=7.4 \mathrm{~Hz}, 3 \mathrm{H}) \cdot{ }^{13} \mathrm{C}$ NMR $\left(126 \mathrm{MHz} \mathrm{CDCl}_{3}\right): \delta$ $=147.6,136.8,122.4(\mathrm{q}, 1 \mathrm{~J} C F=274.7 \mathrm{~Hz}), 121.4,116.9,112.5$, $111.1,69.9,28.4\left(\mathrm{q},{ }^{2} J C F=40.8 \mathrm{~Hz}\right), 22.6,10.6,{ }^{19} \mathrm{~F}$ NMR $(471 \mathrm{MHz}$, 
$\left.\mathrm{CDCl}_{3}\right): \delta=-65.2$. HRMS (ESI) $\mathrm{m} / \mathrm{z}[\mathrm{M}+\mathrm{H}]+$ calcd for $\mathrm{C}_{11} \mathrm{H}_{13} \mathrm{~F}_{3} \mathrm{~N}_{3} \mathrm{O}$ 260.1011, found 260.1010 .

(23) Cellular Responses with Cell-Based Assay

The hT1R2-hT1R3 and G16-gust44 cell lines (approx 80,000 cells) were treated in 96-well black-wall plates with a calcium indicator dye (FLIPR Calcium 4) for 1 hour at $37^{\circ} \mathrm{C}$. Fluorescence changes by excitation at $485 \mathrm{~nm}$, emission at $525 \mathrm{~nm}$, were monitored at 2 seconds intervals. The photoreactive compounds $(6,10,22)$ and sucrose (as positive control) were added at 20 seconds, and scanning was continued for an additional 4 minutes.

(24) Imada, T.; Misaka, T.; Fujiwara, S.; Okada, S.; Fukuda, Y.; Abe, K. Biochem. Biophys. Res. Commun. 2010, 397, 220. 